\title{
KORELASI KOMUNISME DALAM DEMOKRASI DI INDONESIA
}

\author{
Tomy Michael \\ Fakultas Hukum Universitas 17 Agustus 1945 Surabaya \\ Korespondensi: tomy@untag-sby.ac.id
}

\begin{abstract}
Abstrak
Komunisme di Indonesia memiliki stigma buruk akibat bercampurnya dengan unsur politik. Hal ini secara khusus tampak dalam proses pemilihan ketua partai di Indonesia, di mana pada setiap Anggaran Dasar/Anggaran Rumah Tangga kepartaian secara tidak langsung menyiratkan komunisme sebagai ideologi terlarang. Oleh karenanya, muncul paradigma dalam masyarakat bahwa komunisme adalah ideologi yang sesat. Tulisan ini menunjukan bahwa Komunisme tidak memiliki korelasi dalam proses pemilihan ketua partai politik. Proses pemilihan ketua partai politik tidak akan berjalan secara demokrasi apabila dalam Anggaran Dasar/Anggaran Rumah Tangga suatu partai politik tidak mendapatkan legalisasi dari Pemerintah.
\end{abstract}

Kata-kata Kunci: Komunisme; Demokrasi; Partai Politik; Ideologi.

\begin{abstract}
Communism has unfortunately had a bad reputation in Indonesia as a result of the tendency to blend this ideology with political elements. This is particularly apparent in the process of selecting a party chairperson in Indonesia, in which the Statute/Articles of Association of any party indirectly implied that communism is a forbidden ideology. Therefore, the notion that communism is anunacceptable ideology could easily emerge among the members of society. This paper shows that Communism has in fact no significant correlation in the process of selecting the chairperson of a political party. The process of selecting the chair person of a political party will not run in a democratic way if the Statute/Articles of Association of a political party did not obtain previous legalization ofthe Government.
\end{abstract}

Key Words: Communism; Democracy; Political Parties; Ideology. 


\section{PENDAHULUAN}

Hukum hanya akan eksis dalam masyarakat dan tiada masyarakat tanpa ada hukum yang mengatur antara mereka. Itulah salah satu maksim dalam ilmu hukum. Mengacu pada tataran praktik, komunisme di Indonesia memiliki stigma buruk akibat bercampurnya dengan unsur politik. Komunisme dalam kajian ilmu hukum terutama ilmu negara adalah ideologi ${ }^{1}$ yang selalu berkolerasi dengan sistem politik dan mencerminkan suatu gaya hidup yang berdasarkan nilai-nilai tertentu yaitu: ${ }^{2}$

1. Gagasan monisme (sebagai lawan dari pluralisme). Gagasan ini menolak adanya golongan-golongan di dalam masyarakat sebab dianggap bahwa setiap golongan yang berlainan aliran pikir.

2. Kekerasan dipandang sebagai alat yang sah yang harus dipakai untuk mencapai komunisme. Paksaan ini dipakai dalam dua tahap: pertama terhadap musuh, kedua terhadap pengikutnya sendiri yang dianggap masih kurang insaf.

3. Negara merupakan alat untuk mencapai komunisme karena itu semua alat kenegaraan seperti polisi, tentara, kejaksaan, dipakai untuk diabadikan kepada tercapainya komunisme. Ini mengakibatkan suatu campur tangan negara yang sangat luas dan mendalam di bidang politik, sosial dan budaya.

Pentingnya pemahaman akan ideologi agar terciptanya suatu jalan keluar bersifat keilmuan. Dari keseluruhan konsep ilmu sosial, ideologi adalah konsep yang paling kabur, hal ini disebabkan karena ideologi mempersoalkan dasar dan validitas gagasan paling fundamental yang kita miliki. Pada dasarnya ia masih merupakan konsep yang diperdebatkan yaitu konsep tentang definisi dari sesuatu yang mengalami kontroversi akut. Dengan sebuah pengecualian penting, kata "ideologi" telah berarak mengikuti kabut konotasi peyoratif.

Ideologi adalah pemikiran orang lain, sementara pemikiran kita sendiri jarang sekali dianggap ideologi. Bahwa pemikiran kita bisa saja menjadi ideologi merupakan penegasan yang kita tolak dengan penuh semangat, agar landasan konsepsi kita yang kuat tidak berubah menjadi hal yang tidak berguna.

$\overline{1}$ Ideologi adalah ide atau gagasan. Kata ideologi sendiri diciptakan oleh Antoine Destutt de Tracy pada akhir abad ke-18 untuk mendefinisikan "sains tentang ide". Kata ini berasal dari bahasa Perancis idéologie, merupakan gabungan 2 (dua) kata yaitu, idéo yang mengacu kepada gagasan dan logie yang mengacu kepada logos, kata dalam bahasa Yunani untuk menjelaskan logika dan rasio. Ia menggunakan kata ini dalam pengertian etimologinya, sebagai "ilmu yang meliputi kajian tentang asal usul dan hakikat ide atau gagasan". Lebih lengkapnya Perhaps his most famous one was the second of June 20,1796, in which he launched a new (more agnostic) name for this new "science of ideas." It would be called "ideology," the exact Greek transcription of science of ideas, rather than metaphysics, which was too discredited by the Enlightenment even though philosophers continued to use it. Nor could it be called psychology which denotes a knowledge of the soul, which he stated rhetorically "You certainly do not flatter yourselves as having" dalam Emmet Kennedy (Washington), The secularism of Destutt de Tracy's "IDEOLOGY”, pdf, 23.

2 Miriam Budiardjo, Dasar-Dasar Ilmu Politik (PT Gramedia 1981) 87-88. 
Di dalam tulisan ini penulis hanya mengacu pemikiran Karl Marx sebagai acuan D.N. Aidit terkait perkembangan komunisme di Indonesia serta untuk membatasi pembahasan sehingga dapat ditemukan korelasi komunisme dalam demokrasi di Indonesia yang akan dibahas dalam bagian pembahasan.

D.N. Aidit ${ }^{3}$ beragumen bahwa:

Filsafat Marx bersumber pada filsafat klasik Jerman. Filsafat Marxisme adalah materialisme. Hasil yang paling penting dari Marx di bidang filsafat ialah dialektika, yaitu ajaran tentang perkembangan dalam bentuknya yang paling sempurna, paling dalam, bebas dari sifat berat sebelah, ajaran tentang kerelatifan pengetahuan manusia yang memberikan pencerminan kepada kita tentang materi yang berkembang abadi. Marx tidak berhenti pada memperdalam dan mengembangkan materialisme filsafat, tapi ia melengkapinya, ia meluaskan pengertian materialisme filsafat tentang alam kepengertian tentang masyarakat manusia. Penerapan (penggunaan, pelaksanaan) azas-azas pokok materialisme dialektik di lapangan gejala sosial, gejala kemasyarakatan, itulah yang dinamakan materialisme historis. Materialisme filsafat Marx telah menunjukkan kepada Rakyat pekerja jalan keluar dari perbudakan jiwa. Ekonomi Politik Marx bersumber pada ekonomi klasik Inggris. Marx melanjutkan pekerjaan Adam Smith (1723-1790) dan David Ricardo (1772-1823) yang berkat penyelidikannya di lapangan sistem ekonomi telah meletakkan dasar-dasar untuk teori nilai kerja. Marx telah menyingkapkan hubungan antara manusia dalam penukaran antara barang dagangan yang satu dengan barang dagangan yang lain. Dalam hal ini ahli-ahli ekonomi borjuis hanya melihat hubungan antara barang-barang tidak menyingkapkan hubungan antara manusia. Marx membuktikan bahwa dalam sistem kapitalis tenaga kerja manusia pun menjadi barang perdagangan. Dan dari sinilah Marx menjelaskan bagaimana kaum buruh menghasilkan nilai-lebih yang menjadi sumber kekayaan seluruh kelas kapitalis. Ajaran tentang nilailebih adalah batu-alas teori ekonomi Marx. Ekonomi politik Marx menerangkan kedudukan kelas buruh yang sesungguhnya dalam sistem umum kapitalisme. Sosialisme Marx bersumber pada ajaran Sosialisme klasik Prancis. Berbeda dengan ajaran-ajaran sosialisme utopia Prancis, Sosialisme Marx adalah ilmiah, tidak berdasarkan semata-mata pada "kemauan baik" dan "akal" subjektif, tetapi berdasarkan hukum objektif perkembangan masyarakat manusia. Marx telah menarik kesimpulan dari sejarah dunia, bahwa perjuangan kelas adalah lokomotif daripada kemajuan masyarakat, bahwa untuk menciptakan masyarakat sosialis, masyarakat dimana tidak ada penghisapan atas manusia oleh manusia, masyarakat tak berkelas, tidaklah mungkin dengan jalan mengharapkan belas kasihan kaum kapitalis atau usaha orang-orang yang baik budi saja, tetapi harus dengan jalan mengadakan perjuangan kelas terhadap kaum kapitalis. Perjuangan kelas untuk menghapuskan kelas!.

Literatur lainnya juga menjelaskan bahwa Karl Marx sendiri tidak pernah mengakui bahwa ia adalah seorang Marxis. Pernyataan tersebut menandakan bahwa Karl Marx tidak pernah menganggap buah pikirannya dijadikan sebagai dogma ideologis apalagi sebagai sistem sebuah negara. Filsafat Karl Marx memang mencita-citakan sebuah masyarakat komunis (tanpa kelas) di mana tiap orang diminta menurut kecakapannya, dan kepada tiap orang diberikan menurut kebutuhannya. Tujuan masyarakat komunis tersebut memang membutuhkan sebuah alat,

\footnotetext{
D.N. Aidit, Tentang Marxisme (Akademia Ilmu Sosial Aliarcham 1963) 8-10.
} 
dan Karl Marx berpendapat bahwa negara merupakan alat yang mungkin untuk mewujudkannya. Karl Marx meminjam konsep negara untuk mewujudkan cita-citanya tersebut dari Hegel, namun ia mengkritik konsep negara Hegel sebagai perwujudan dari "Roh Suci". Bagi Karl Marx, negara selama ini digunakan sebagai alat bagi pihak yang berkuasa untuk melanggengkan kekuasaannya. Pendapat Karl Marx tersebut diperoleh dari pemahaman bahwa masyarakat sebenarnya selalu berada dalam kondisi pertentangan antar kelas (kelas penguasa dan kelas yang dikuasai). Setiap pertarungan kelas yang terjadi selalu dimenangkan oleh pihak penguasa sehingga mereka dapat dengan mudah membodohi kelas yang dikuasai melalui mekanismemekanisme kenegaraan (lembaga, produk dan sistem). Karl Marx kemudian menganjurkan sebuah revolusi yang dipimpin oleh kelas yang dikuasai untuk merebut negara yang kemudian secara sementara mewujudkan masyarakat tanpa kelas. Setelah masyarakat komunis tercipta maka negara tidak dibutuhkan lagi. Pandangan Karl Marx tentang negara mau tidak mau mempengaruhi pemikirannya tentang hukum. Bagi Karl Marx, "hukum (Recht) anda adalah kemauan dari kelas anda yang diangkat menjadi undang-undang (Gesetz), suatu kemauan yang memperoleh isinya dari kondisi material dari eksistensi Anda. ${ }^{4}$

Pemikiran lainnya yaitu hubungan negara dan hukum dalam asumsi Karl Marx merupakan cerminan dari faktor ekonomi. ${ }^{5}$ Negara dan hukum menurut Karl Marx merupakan sebuah refleksi dari kenyataan sosial. Kenyataan yang ia tangkap saat itu adalah adanya kekuatan kelas penguasa yang dominan. Ia kemudian mengidentikkan hukum sebagai hubungan produksi yang dikaitkan dengan negara sebagai sebuah ideologi. Ideologi diartikan menurut Karl Marx secara negatif yaitu sebagai kekuatan untuk "mengakali" realitas supaya dianggap sebagai realitas aslinya. ${ }^{6}$

Ketika ideologi berubah menjadi alat propaganda maka di situlah terjadi politisasi dalam kehidupan berbangsa dan bernegara. ${ }^{7}$ Komunisme di Indonesia yang dianggap sebagai larangan

$4 \quad$ B. Arief Sidharta, Sejarah dan Masalah-Masalah Hukum (Laboratorium Hukum Fakultas Hukum Universitas Katolik Parahyangan 2005) 19.

5 Pemahaman akan hubungan negara dan hukum dipaparkan dengan baik ketika suatu perangkat prinsip atau perangkat asas dan perangkat kaidah hukum positif yang merupakan bagian-bagian yang tidak terpisahkan dan teramat penting dari suatu hukum positif yang keseluruhannya telah dirancang menurut pola tertentu. Saling berkaitan erat antara satu bagian dengan bagian yang lain dan saling bahu membahu antara satu unsur dengan unsur yang lainnya dalam satu kesatuan tujuan. Hal ini disebut dengan teori keadilan bermartabat, lebih lanjut dalam Teguh Prasetyo, Sistem Hukum Pancasila (Nusa Media 2016) 28-29.

Hans Kelsen, The Communist Theory of Law (Praeger, Inc 1955) 11-12.

David McLellan, Ideologi Tanpa Akhir (Kreasi Wacana 2014) 1-2. Di dalam buku ini terdapat dua perbedaan yaitu pendekatan pertama membedakan secara tegas ideologi dan sains. Dalam tradisi rasionalis Perancis Antoine Destutt de Tracy, penerapan rasio ke dalam masyarakat akan membebaskan masyarakat itu sendiri dari prasangka-prasangka irasional yang telah begitu berbahaya di masa silam dimana pengetahuan tentang ideologi akan menerangi masyarakat 
melalui Ketetapan Majelis Permusyawaratan Rakyat Sementara Republik Indonesia No. XXV/MPRS/ 1966 tentang Pembubaran Partai Komunis Indonesia, Pernyataan Sebagai Organisasi Terlarang Diseluruh Wilayah Negara Republik Indonesia Bagi Partai Komunis Indonesia dan Larangan Setiap Kegiatan Untuk Menyebarkan atau Mengembangkan Faham atau Ajaran Komunisme/ Marxisme-Leninisme (TAP MPRS No. XXV/MPRS / 1966) dimana pada bagian konsiderans termaktub bahwa "Bahwa faham atau ajaran Komunisme/Marxisme-Leninisme pada inti hakekatnya bertentangan dengan Pancasila".

Ideologi yang berubah menjadi alat propaganda juga ditemukan dalam buku "Ideologi Jerman" bahwa sejarah dipandang dari dua ilmu yaitu sejarah alam dan sejarah manusia dimana keduanya saling terkait. Sejarah manusia memiliki peranan penting dalam kehidupan karena hampir semua ideologi yang berkembang menjadi konsep sejarah manusia yang menyimpang atau abstraksi murni darinya. ${ }^{8} \mathrm{Di}$ dalam hal ini penulis menekankan bahwa pemahaman terhadap komunisme di Indonesia bukanlah dalam tataran ilmu pengetahuan karena masih tercampur stigma buruk akan subjek hukum-subjek hukum tertentu yang menginginkan kekuasaan atas nama komunisme. Komunisme di Indonesia tidak dapat dialihkan begitu saja tanpa memahami hakikat komunisme sebenarnya. ${ }^{9}$

\section{PEMBAHASAN}

\section{Hakikat Komunis di Indonesia}

Golongan kelas buruh yang karena yakin bahwa revolusi-revolusi politik saja tidak cukup dan menuntut perombakan masyarakat secara radikal disebut komunis. ${ }^{10}$ Golongan kelas buruh yang dimaksud dalam komunis ini memiliki perbedaan dengan buruhburuh lainnya yaitu menginginkan penghapusan kepemilikan borjuis (bukan penghapusan kepemilikan). Kaum komunis hanya berbeda dengan partai-partai proletariat lainnya bahwa di satu pihak mereka menegaskan dan mempertahankan kepentingan bersama seluruh proletariat dalam perjuangan proletariat di berbagai negeri, tidak bergantung pada kebangsaan. Di lain pihak dalam berbagai tingkatan perkembangan yang harus dilalui oleh perjuangan antara proletariat dengan borjuasi, mereka senantiasa mewakili kepentingan-kepentingan seluruh gerakan. ${ }^{11}$

\footnotetext{
Karl Marx dan Frederich Engels, Ideologi Jerman Jilid I, Feurbach (Pustaka Nusantara 2013) 7- 8. Pemahaman akan komunisme juga penulis kaitkan dengan pemilihan ketua partai politik di Indonesia. Argumen ilmiah mengapa harus dikaitkan dengan pemilihan ketua partai politik di Indonesia disebabkan komunisme di Indonesia merupakan ideologi yang dimiliki Partai Komunis Indonesia.

10 Karl Marx dan Frederich Engels, Manifesto Partai Komunis (Ultimus 2015) 19. Di dalam tulisan ini, penulis juga membandingkan dengan literatur berjudul sama yaitu Karl Marx dan Frederich Engels, Manifesto Partai Komunis (Cakrawangsa Yogyakarta 2014) 19- 25 tetapi penulis lebih menggunakan literatur pertama terbitan Ultimus dikarenakan redaksi terjemahan lebih sempurna.

11 Karl Marx dan Frederich Engels, Op. Cit. 45.
} 
Mengacu pada karya D.N. Aidit, dijelaskan bahwa Partai Komunis Indonesia (PKI) yang lahir tahun 1920 mengatakan tidak akan mencampuri soal-soal internal daripada partai-partai lain walau untuk mempersatukannya sekalipun. Itu adalah soal daripada partai-partai yang bersangkutan sendiri. Kewajiban PKI ialah mengajak partai-partai apa saja yang sedia dan jujur untuk bekerja sama dengan PKI guna menggalang front persatuan nasional dan front-front persatuan di berbagai kalangan, di kalangan kaum buruh, kaum tani, kaum terpelajar, kaum pecinta dan ahli kebudayaan, kaum wanita, pemuda, pengusaha dan lain-lain. ${ }^{12}$ Oleh karena itu, kaum komunis secara praktik adalah bagian yang paling teguh, bagian yang terus mendorong maju bagian-bagian lainnya dari partai-partai buruh di semua negeri; secara teori mereka mempunyai kelebihan pengertian dari masa proletariat lainnya tentang syarat-syarat, proses dan hasil-hasil umum gerakan proletar.

Dimana dijelaskan bahwa gerakan yang memperjuangkan emansipasi dan keadilan sosial yang biasa disebut "gerakan kiri" memiliki spektrum yang luas: merentang dari gerakan-gerakan yang memperjuangkan kesetaraan gender dan hak-hak kaum perempuan, hak-hak ekonomi, sosial dan budaya, dan yang memperjuangkan keadilan lingkungan (ecological justice). Mereka muncul dalam beragam kelompok gerakan buruh dan kaum pekerja, kaum tani dan nelayan, kaum perempuan, pemuda, dan lain sebagainya, dengan ideologi perjuangan yang juga beragam: sosialisme, komunisme, anarkisme, hingga populisme. Dalam sejarahnya, gerakan-gerakan kiri banyak pula yang berbalut dengan perjuangan pembebasan nasional (nasionalisme), dan melakukan aksiaksi revolusionernya dengan beragam cara dalam rentang "revolusi sosial" di satu titik hingga ke "revolusi jalan parlementer" di titik lainnya. ${ }^{13}$

Di dalam Manifesto Partai Komunis dikatakan bahwa tuduhan komunis hendak menghapuskan tanah air dan kebangsaan seperti yang dituduhkan kaum borjuis merupakan kesalahan besar. Kaum buruh tidak mempunyai tanah air. Dari mereka tidak dapat diambil apa yang mereka tidak punyai.

12 D. N. Aidit, Menempuh Jalan Rakyat (Sega Arsy 2014) 22. Penulis juga menggunakan literatur Sekretariat Negara Republik Indonesia, Gerakan 30 September Pemberontakan Partai Komunis Indonesia: Latar Belakang, Aksi dan Penumpasannya (Sekretariat Negara Republik Indonesia 1994) 24-25 bahwa D N Aidit menyusun program partai untuk mencapai tujuannya yaitu mengkomuniskan Indonesia. Adapun isi program tersebut adalah sebagai berikut: a. Membina front persatuan nasional yang berdasrkan persatuan kaum buruh dan kaum tani, b.

Membangun PKI yang meluas di seluruh negara dan mempunyai karakter massa yang luas, yang sepenuhnya terkonsolidasi di lapangan ideologi, politik, dan organisasi.

Taktik PKI pada masa kepemimpinan D.N. Aidit ialah dengan memakai model Partai Komunis Uni Soviet dan model Partai Komunis Cina sekaligus, disesuaikan dengan kondisi nyata di Indonesia.

13 Penulis juga menggunakan Bilven, Sejarah Gerakan Kiri Indonesia untuk Pemula (Ultimus 2016) IX sebagai literatur pelengkap naskah Karl Marx dan Frederich Engels, Manifesto Partai Komunis (Ultimus 2015). 
Oleh karena proletariat pertama-tama harus merebut kekuasaan politik, harus mengangkat dirinya menjadi kelas yang bersifat nasional. ${ }^{14}$

Bahwa PKI adalah sintesa dari pada gerakan buruh Indonesia dengan Marxisme-Leninisme. PKI didirikan pada tanggal 23 Mei 1920 bukanlah sebagai sesuatu yang kebetulan, tetapi sesuatu yang obyektif. PKI lahir dalam jaman imperialisme, sesudah di Indonesia ada kelas buruh, sesudah di Indonesia dibentuk serikat buruh-buruh dan dibentuk ISDV (Indonesische Sociaal Democrastische Vereniging), sesudah Revolusi Sosialis Oktober Rusia tahun 1917. PKI adalah anak jaman yang lahir pada waktunya. Bahwa lahirnya PKI karena keharusan jaman menjadi jelas dari tulisan Kawan Stalin dalam bukunya "Dasar-Dasar Leninisme" sebagai berikut:

Imperialisme ialah eksploitasi (pemerasan) yang paling tidak kenal malu dan penindasan yang paling tidak berperikemanusiaan terhadap beratus-ratus juta manusia yang mendiami kolonikoloni yang luas dan negeri-negeri yang tergantung. Tujuan dari eksploitasi dan penindasan ini ialah untuk mendapat keuntungan-keuntungan luar biasa. Tetapi dalam mengeksploitasi negerinegeri ini imperialisme terpaksa membikin jalan-jalan kereta api, pabrikpabrik, dan perusahaan-perusahaan di situ, menciptakan pusat-pusat industri dan perdagangan. Timbulnya suatu kelas kaum proletar, munculnya inteligensia bumi putera, bangunnya kesadaran nasional, tumbuhnya gerakan untuk kemerdekaan - demikianlah akibat-akibat yang tidak dapat dihindari dari "politik" ini. Pertumbuhan dari pada gerakan revolusioner di semua koloni dan negeri-negeri tergantung dengan tidak ada kecualinya membuktikan dengan jelas kenyataan ini. Keadaan ini adalah penting bagi proletariat karena ia dengan radikal melemahkan kedudukan kapitalisme dengan mengubah koloni-koloni tergantung dari cadangancadangan imperialisme menjadi cadangan-cadangan revolusi proletar. ${ }^{15}$

Komunisme yang pada mulanya di Indonesia merupakan ajang untuk melawan kekuasaan Belanda maka dalam perjalanannya menjadi terpecah belah sehingga dengan demikian menjadi politisasi banyak pihak. Makna terpecah belah dijelaskan sebagai berikut:

Kesalahan pokok pemimpin-pemimpin PKI ketika itu ialah bahwa mereka telah menjadi mangsa dari pada semboyansemboyan kekiri-kirian, tidak berusaha keras untuk menjelaskan keadaan, mau memecahkan semua soal dengan satu kali pukul seperti: melikuidasi feodalisme, melepaskan diri dari Belanda, menghancurkan semua kaum imperialis, menggulingkan pemerintah yang reaksioner, melikuidasi kaum tani kaya, melikuidasi kaum borjuis nasional. Dengan sendirinya, akibat dari pada ini semua ialah timbul persatuan di antara musuh yang sejati dengan yang bisa menjadi musuh untuk bangkit melawan Partai. Ini berakibat Partai mengisolasi diri sendiri dan ini sangat melemahkan Partai. Partai tidak cukup mengarahkan perhatian anggota-anggotanya kepada pekerjaan-pekerjaan praktis yang kecilkecil, yang remeh-remeh yang ada hubungannya dengan kebutuhan sehari-hari dari kaum buruh, kaum tani, dan kaum intelektual pekerja. Padahal hanya di sini, dalam pekerjaan ini, Partai bisa mempersatukan massa pekerja yang luas di sekeliling Partai. Sudah tentu, pekerjaan ini bukannya pekerjaan yang menyenangkan atau enak dan sonder kesukaran-kesukaran. Tetapi, jalan lain

$14 \quad$ Karl Marx dan Frederich Engels, Manifesto Partai Komunis Op. Cit. 51-52.

15 D. N. Aidit, Lahirnja PKI dan Perkembannganja (Jajasan Pembaruan 1955) 8-9. 
tidak ada untuk mengeratkan hubungan Partai dengan massa pekerja. ${ }^{16}$

\section{Hakikat Demokrasi dalam Proses Pemilihan Ketua Partai}

Guna mengetahui hakikat demokrasi dalam proses pemilihan ketua partai di Indonesia, penulis melakukan pembagian analisa secara singkat proses pemilihan ketua partai politik berdasarkan:

1. Pasal 4 Anggaran Dasar/Anggaran Rumah Tangga Partai Islam Damai Aman Tahun 2015, dijelaskan bahwa pengurus pusat terdiri dari dewan pembina dan dewan syuro ditetapkan oleh ketua umum.

2. Pasal 8 Anggaran Dasar/Anggaran Rumah Tangga Partai Keadilan dan Persatuan Indonesia Tahun 2015, dijelaskan bahwa ketua umum dipilih oleh kongres.

3. Pasal 22 Anggaran Dasar/Anggaran Rumah Tangga Partai Keadilan Sejahtera Tahun 2013, dijelaskan bahwa dewan pengurus pusat dipimpin oleh presiden partai.

4. Pasal 12 Anggaran Dasar/Anggaran Rumah Tangga Partai Kebangkitan Bangsa Tahun 2008, dijelaskan bahwa dewan pengurus pusat adalah pimpinan tertinggi partai.

e. Pasal 18 Anggaran Dasar/Anggaran Rumah Tangga Partai Gerakan Indonesia Raya Tahun 2012, dijelaskan bahwa dewan pembina dipimpin oleh ketua dewan pembina. f. Pasal 16 Anggaran Dasar/Anggaran Rumah Tangga Partai Aceh Tahun 2007, dijelaskan bahwa ketua pimpinan dipilih dengan musyawarah besar.

g. Pasal 27 Anggaran Dasar/Anggaran Rumah Tangga Partai Komunis Indonesia,dijelaskan bahwa semua badan pimpinan partai dipilih:

a. CC dipilih oleh Kongres Nasional Partai;

b. CDB, CP, CK, CS, dan CSS dipilih oleh Konferensi-Konferensi Partai daerah masing-masing;

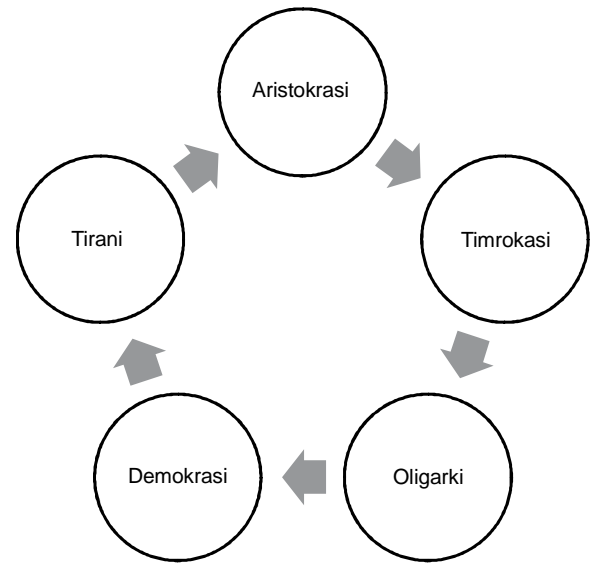

c. CR dipilih oleh Rapat Resort, dan CRB dipilih oleh Konferensi Resort Besar. ${ }^{17}$

Berdasarkan pembahasan di atas, diketahui bahwa proses pemilihan ketua partai cenderung berdasarkan pimpinan atau kongres dimana anggotanya berkumpul.

Sebelum memasuki esensi demokrasi maka penulis memaparkan beberapa pemikiran tokoh terkait demokrasi yaitu:

Ibit.13.

Bintang Merah Nomor Spesial, "Maju Terus” Jilid I. Kongres Nasional Ke-VII(Luar Biasa) Partai Komunis Indonesia (Yayasan Pembaruan 1963). 
1. Socrates ${ }^{18}$ mengungkapkan 5 (lima) bentuk pemerintahan sesuai dengan sifat manusia yaitu:

a. Aristokrasi dimana pemerintahan dipegang oleh kaum bijaksana.

b. Timokrasi dimana pemerintahan dipegang oleh orang-orang yang ingin mencapai kemasyhuran dan kehormatan.

c. Oligarki dimana pemerintahan dipegang oleh kaum hartawan.

d. Demokrasi dimana pemerintahan dipegang oleh rakyat jelata.

e. Tirani dimana pemerintahan oleh seorang yang bertindak sewenangwenang.

2. Aristoteles ${ }^{19}$ mengungkapkan 6 (enam) bentuk pemerintahan berdasarkan jumlah orang yang memegang pucuk pemerintahan dan kualitas pemerintahannya yaitu:

a. Monarki (satu orang pimpinan), demi kepentingan umum, sifatnya baik dan ideal.

b. Tirani (satu orang pimpinan) demi kepentingan pribadi, sifatnya buruk dan kemerosotan.

c. Aristokrasi (dipimpin sekelompok cendekiawan) demi kepentingan umum, sifatnya baik dan ideal.

d. Oligarki (dipimpin sekelompok cendekiawan) demi kepentingan kelompoknya, sifatnya buruk dan kemerosotan.

e. Politeia (pemerintahan konstitusional).

f. Demokrasi (dipimpin orang-orang tertentu demi kepentingan sebagian orang), sifatnya buruk dan kemerosotan.

3. Polybius ${ }^{20}$

Anacyclosis from Polybius:

a. Monarki (masyarakat primitif).

b. Kingship (ada kekuatan dalam moral dan keadilan).

c. Tirani (satu orang pria terbaik).

d. Aristokrasi (korupsi).

e. Oligarki (masyarakat memberontak).

f. Demokrasi (semua memimpin).

g. Oklorasi (biadab/kekacauan).

h. Monarki baru.

4. Jean Jacques Rousseau ${ }^{21}$

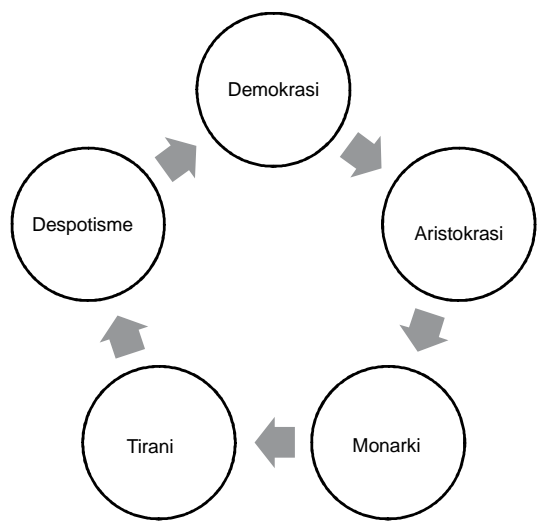

a. Demokrasi (penguasa menjadikan rakyat sebagai hakim).

18 Lebih lanjut dalam Plato, Republik (Bentang Budaya 2002) dan Plato, The Great Dialogues Of Plato (Penguin Books Canada Limited 1984).

19 Lebih lanjut dalam Aristoteles, Politik (La Politica) (Visimedia 2008); Aristoteles, Politik (Bentang Budaya 2004) dan Aristotle, The World's Great Classics (Grolier).

20 Lebih lanjut dalam Polybius, The Rise Of The Roman Empire (Penguin Books).

21 Lebih lanjut dalam Jean-Jacques Rousseau, The Social Contract (Penguin Books); Jean-Jacques Rousseau, Perihal Kontrak Sosial Atau Prinsip-Prinsip Hukum Politik (Dian Rakyat 1989); JeanJacques Rousseau, Du Contract Social (Perjanjian Sosial) (Visimedia 2009) dan Jean-Jacques Rousseau, Perihal Kontrak Sosial Atau Prinsip Hukum Politik (Dian Rakyat 2010). 
b. Aristokrasi (penguasa menjadikan rakyat berkelompok sebagai hakim).

c. Monarki (kehendak umum= kepentingan bersama hanya hanya satu).

d. Tirani (percaya pada diri sendiri, bertentangan dengan undangundang). Tiran tidak dapat menjadi despotis.

e. Despotisme (sewenang-wenang). Despotis dapat menjadi tiran.

5. St Thomas Aquinas ${ }^{22}$

a. Kingship (King adalah pemimpinnya dan Father adalah panggilan dari masyarakat).

b. Tirani (seorang diri, segala sesuatu dari satu orang), setan berasal dari sini.

c. Oligarki (tidak terdapat perbedaan dengan tirani, hanya jumlah saja), polity.

d. Demokrasi (kontrol dari masyarakat), polity.

e. Aristokrasi (noble man called optimates)

f. Langsung ke Tirani tetapi tanpa meninggalkan Kingship namun tetap bersumber pada Tuhan.

g. St Thomas Aquinas terinspirasi Aristoteles yang menyatakan kebenaran moral untuk kebaikan dari-pada Plato yang menyatakan kebenaran ide.
Di dalam berbagai pemikiran tokoh di atas, demokrasi bukanlah suatu bentuk pemerintahan yang terbaik karena kualitas bentuk pemerintahan terdapat pada kuantitas pemimpin. ${ }^{23}$ Jumlah pemimpin semakin sedikit maka akan semakin baik bentuk pemerintahan yang dianut dalam suatu negara. Hakikat demokrasi yang diperoleh bahwa proses pemilihan ketua partai politik tidak tergantung pada bentuk pemerintahan dan ideologi suatu negara hal ini dikarenakan hakikat partai apabila mengacu Pasal 1 angka 1 Undang-Undang Republik Indonesia Nomor 2 Tahun 2008 tentang Partai Politik (UU No. 2 Tahun 2008) yaitu:

Organisasi yang bersifat nasional dan dibentuk oleh sekelompok warga negara Indonesia secara sukarela atas dasar kesamaan kehendak dan citacita untuk memperjuangkan dan membela kepentingan politik anggota, masyarakat, bangsa dan negara, serta memelihara keutuhan Negara Kesatuan Republik Indonesia berdasarkan Pancasila dan Undang-Undang Dasar Negara Republik Indonesia Tahun 1945.

Frasa "memperjuangkan dan membela kepentingan politik anggota" cenderung mengakibatkan proses pemilihan ketua partai tidak berjalan secara adil dimana esensi partai politik karena apabila mengacu Pasal 3 ayat (1) Undang-Undang Republik Indonesia Nomor 2 Tahun 2011 tentang Perubahan

\footnotetext{
Lebih lanjut dalam Dino Bigongiari, The Political Ideas of St. Thomas Aquinas (Hafner Press 1981). Di dalam kepustakaan ilmu politik, bentuk pemerintahan berbeda dengan bentuk negara. Perbedaan antara bentuk negara dan bentuk pemerintahan adalah bentuk negara mengenai negara secara kesatuan atau negara dilihat dari luar. Atau dapat dilukiskan juga bentuk negara menggambarkan dasar negara negara, susunan negara, lebih lanjut dalam Hotma P Sibuea, Imu Negara (Erlangga 2014).
} 
Atas Undang-Undang Nomor 2 Tahun 2008 Tentang Partai Politik (UU No. 2 Tahun 2011) termaktub bahwa partai politik harus didaftarkan ke kementerian untuk menjadi bahan hukum.

\section{PENUTUP}

Komunisme di Indonesia menjadi buruk keberadaannya karena adanya unsur politisasi sehingga muncul paradigma dalam masyarakat bahwa komunisme adalah ideologi yang sesat bahkan pemerintah juga memiliki sikap tidak peduli menyajikan kebenaran tentang landasan filosofis dari ideologi komunisme. Hal ini terlihat dari adanya penetapan dan pencabutan Ketetapan Majelis Permusyawaratan Rakyat Sementara Republik Indonesia No. XXX/MPRS/1966 tentang Pencabutan Bintang "Maha Putera" Kelas III dari D.N. Aidit.

Komunisme juga tidak memiliki korelasi dalam proses pemilihan ketua partai politik karena kehendak atas suatu partai politik berdasarkan sekelompok anggota di dalamnya. ${ }^{24}$ Selain itu, proses pemilihan ketua partai politik tidak akan berjalan secara demokrasi apabila dalam Anggaran Dasar/Anggaran Rumah Tangga suatu partai politik tidak mendapatkan legalisasi dari kementerian seperti yang dimaksud dalam UU No. 2 Tahun 2011. Legalisasi yang dimaksud agar tercipta suatu bentuk pertanggung- jawaban dari suatu partai politik mengingat dari partai politiklah muncul kepala daerah, presiden, wakil presiden dan partai politik dapat menyebabkan politik hukum yang mempengaruhi sistem dan bentuk pemerintahan suatu negara.

Agar paradigma komunisme di Indonesia mengalami perubahan mengenai hakikat komunisme yang sebenarnya, maka salah satu caranya yaitu proses pemilihan ketua partai politik berjalan harus sesuai Pasal 1 ayat (3) Undang-Undang Dasar Negara Republik Indonesia Tahun 1945 yaitu "Negara Indonesia adalah negara hukum" maka hal yang perlu menjadi agenda percakapan yaitu meninjau kembali Pasal 2 Ketetapan Majelis Permusyawaratan Rakyat Republik Indonesia Nomor 1/MPR/2003 tentang Peninjauan Kembali Materi Dan Status Hukum Ketetapan Majelis Permusyawaratan Rakyat Sementara Dan Ketetapan Majelis Permusyawaratan Rakyat Indonesia Tahun 1960 Sampai Dengan Tahun 2002 bahwa Ketetapan Majelis Permusyawaratan Rakyat Sementara Republik Indonesia No. XXV/MPRS/ 1966 tentang Pembubaran Partai Komunis Indonesia, Pernyataan Sebagai Organisasi Terlarang Di seluruh Wilayah Negara Republik Indonesia Bagi Partai Komunis Indonesia Dan Larangan Setiap Kegiatan Untuk Menyebarkan Atau Mengembangkan

$\overline{24} \quad$ Hal ini menjadi penting karena di dalam kehidupan berbangsa dan bernegara, keberadaan suatu partai politik (terutama dalam pemilihan ketua partai politik) di dalam negara, seolah-olah menunjukkan bahwa negara tersebut pasti murni demokrasi (bentuk pemerintahan) padahal sebuah ideologi tidak terjadi karena bentuk pemerintahan suatu negara tetapi bentuk negara dipengaruhi oleh ideologi yang dianut oleh suatu negara. 
Faham Atau Ajaran Komunisme/ Marxisme-Leninisme. Bagi Penulis Komunisme / Marxisme-Leninisme tidak akan mungkin berkembang di Indonesia kecuali dalam tataran ilmu pengetahuan.

\section{DAFTAR BACAAN}

\section{Buku}

Aidit, D.N., Lahirnja PKI Dan Perkembannganja (Jajasan Pembaruan 1955).

, Tentang Marxisme (Akademia Ilmu Sosial Aliarcham 1963).

, Menempuh Jalan Rakyat (Sega Arsy 2014).

Aristoteles, Politik (Bentang Budaya 2004).

, Politik (La Politica) (Visimedia 2008).

Aristotle, The World's Great Classics (Grolier).

Bigongiari, Dino, The Political Ideas of St. Thomas Aquinas (Hafner Press 1981).

Bilven, Sejarah Gerakan Kiri Indonesia Untuk Pemula (Ultimus 2016).

Bintang Merah Nomor Spesial, "Maju Terus" Jilid I. Kongres Nasional KeVII (Luar Biasa) Partai Komunis Indonesia (Yayasan Pembaruan 1963.

Budiardjo, Miriam, Dasar-Dasar Ilmu Politik (PT Gramedia 1981).
Kelsen, Hans, The Communist Theory of Law (Frederick A. Praeger, Inc 1955).

Kennedy (Washington), Emmet, The secularism of Destutt de Tracy's "IDEOLOGY".

Marx, Karl dan Frederich Engels, Ideologi Jerman Jilid I, Feurbach (Pustaka Nusantara 2013). , Manifesto Partai Komunis (Cakrawangsa Yogyakarta 2014). , Manifesto Partai Komunis (Ultimus, 2015).

McLellan, David, Ideologi Tanpa Akhir (Kreasi Wacana 2014).

Plato, The Great Dialogues of Plato (Penguin Books Canada Limited 1984).

_-_-_, Republik (Bentang Budaya 2002).

Polybius, The Rise of The Roman Empire (Penguin Books).

Prasetyo, Teguh, Sistem Hukum Pancasila (Nusa Media 2016).

Republik Indonesia, Sekretariat Negara, Gerakan 30 September Pemberontakan Partai Komunis Indonesia: Latar Belakang, Aksi Dan Penumpasannya (Sekretariat Negara Republik Indonesia 1994).

Rousseau, Jean-Jacques, Perihal Kontrak Sosial Atau PrinsipPrinsip Hukum Politik (Dian Rakyat 1989). 
_. Du Contract Social (Perjanjian Sosial) (Visimedia 2009).

_____-, Perihal Kontrak Sosial Atau Prinsip Hukum Politik (Dian Rakyat 2010).

___ The Social Contract (Penguin Books).

Sibuea, Hotma P, Ilmu Negara (Erlangga 2014).

Sidharta, B. Arief, Sejarah dan MasalahMasalah Hukum (Laboratorium Hukum Fakultas Hukum Universitas Katolik Parahyangan 2005). 
[Vol. 1, No. 1 